\title{
Land Use/Cover and Productivity in the Compact Agricultural Areas of Mexico
}

\author{
Jesús Soria-Ruiz¹, Yolanda Fernandez-Ordoñez ${ }^{2}$, Guillermo Medina-Garcia ${ }^{3}$, \\ Gabriel Diaz-Padilla4 \\ ${ }^{1}$ Geomatics Lab, National Institute of Research for Forestry Agricultural and Livestock (INIFAP), Zinacantepec, \\ Mexico \\ ${ }^{2}$ Postgraduate College in Agricultural Sciences (COLPOS) Campus Montecillo, Texcoco, México \\ ${ }^{3}$ National Institute of Research for Forestry Agricultural and Livestock (INIFAP), Zacatecas, Mexico \\ ${ }^{4}$ Agromaps-Lab, National Institute of Research for Forestry Agricultural and Livestock (INIFAP), Veracruz, \\ Mexico \\ Email: soria.jesus@inifap.gob.mx, yfernand@colpos.mx, medina.guillermo@inifap.gob.mx, \\ diaz.gabriel@inifap.gob.mx
}

Received 21 September 2014; revised 16 October 2014; accepted 8 November 2014

Copyright (C) 2014 by authors and Scientific Research Publishing Inc.

This work is licensed under the Creative Commons Attribution International License (CC BY).

http://creativecommons.org/licenses/by/4.0/

(c) (i) Open Access

\begin{abstract}
This paper presents a method to associate land use/cover with productivity in 16 Agrotech Observatories (AOTs) in Mexico. Compact agricultural areas in Mexico have been identified, which are monitored as to their behavior concerning production and rural productivity in a network of AOTs, which is a compact agricultural area representative of agro-ecological, technological and social conditions in the country. To optimize production and agricultural productivity in compact areas, a multidisciplinary and holistic approach with four lines of activity (agro-ecological, technological, economic, and social), and ten actions are used. The objective of this work was to obtain the land use/cover and productivity of sixteen compact agricultural areas (AOTs) in the Mexican Republic, using panchromatic and multispectral SPOT 5 imagery, in order to provide information to the agricultural sector of the country, and to support decision making contributing to the optimization of production in areas with high actual and potential productivity. As an example, in this paper the land use/cover and productivity "AOT 20 Hidalgo" were described. Currently, it is important to have updated and accurate information to support actions and programs of federal, state and local government for farmers, particularly in compact areas with high agricultural production potential.
\end{abstract}

\section{Keywords}

Land Use/Cover, Productivity, SPOT Images, Agrotech Observatories, Mexico 


\section{Introduction}

Land use is the human modification of the Earth's surface, which has strongly affected and will increasingly shape planetary functions [1]. Looming sustainability problems such as climate change, increasing demand for food, accelerating urbanization, the ongoing biodiversity crisis and widespread changes in the structure and functioning of ecosystems with implications for the services they provide all indicate that research at the interface of humans and the environment will continue to be of utmost societal relevance [2]. Land use is a key for understanding and potentially solving these sustainability challenges, and land-use science therefore remains a critical topic for academic study as it contributes to better understanding human-environment interactions across different spatial and temporal scales and to outlining pathways towards sustainable resource use.

Land-use science, also called land-change science [3] [4], and land-system science [5] [6], is the study of changes in land at the interface of social and environmental systems and their implications for the global environment [7]. The Earth's land cover characteristics and its use are key variables in global change. Land cover refers to the vegetation and artificial structures that cover the land's surfaces. Examples of land cover include trees, grass, crops, wetlands, water, buildings and pavements. Land cover maps are made from remotely sensed images. Scientists interpret those images by relating specific colors, tones, patterns, shapes, sizes and features to specific types of land cover [8]. The importance of land cover data is to study the economic impact of land cover and productivity, as well as its effect on water quality, the spread of invasive species, habitat and biodiversity loss, climate variability, and other environmental factors. National government requires up-to-date land cover information to accurately understand current condition and to assess the extent and impacts of land cover change on the Earth. One notable contribution in mapping land-use change include approaches to implement standards for characterization and validation of land-cover maps [9], and analyses of the mismatch between land use versus land cover [10].

For the Mexican government, the gradual and sustainable increase in productivity and competitiveness in compact agricultural areas of the country is important; this initiative is supported by the application of knowledge generated in agricultural research institutions and universities. Pursuing this initiative at the national level is a complex task due to the diversity of agro-ecological and socio-economic factor combinations. Compact agricultural areas in Mexico have been identified by a group of experts; they are monitored as to their behavior concerning production and rural productivity in a network of Agrotech Observatories, also named Compact Agricultural Areas (AOTs). So, an AOT is a compact agricultural area representative of agro-ecological, technological and social conditions in the country. A multidisciplinary team of scientists and researchers analyze and define the best production options for the different types of producers in these areas in order to maximize profits and minimize risks. To optimize production and agricultural productivity in compact areas, a multidisciplinary and holistic approach with four lines of activity (agro-ecological, technological, economic, and social), and ten actions are established. The objective of this work was to obtain the land use/cover and productivity of sixteen AOTs in the Mexican Republic, using panchromatic and multispectral SPOT 5 imagery, in order to provide information to the agricultural sector of the country, and to support decision making contributing to the optimization of production in areas with high actual and potential productivity.

\section{Materials and Methods}

\subsection{Compact Agricultural Areas (AOTs)}

This work was carried out during 2011. The criteria used for selecting the 16 compact agricultural areas of the country were: 1) Use the cartography of the agricultural borderline; 2) Generate a national coverage mesh with cells, each one of 10,000 hectare; 3) Select cells with greater than or equal to 6000 ha of agricultural area and delineate AOTs to contain ten or more selected cells (Figure 1).

\subsection{Characterization of AOTs}

All compact agricultural areas were characterized according to geographical location, climate and soil conditions, actual and historical crops yields. As shown in Table 1, these AOTs involve 14 states of the Mexican Republic covering a total surface of 2,470,000 ha. 


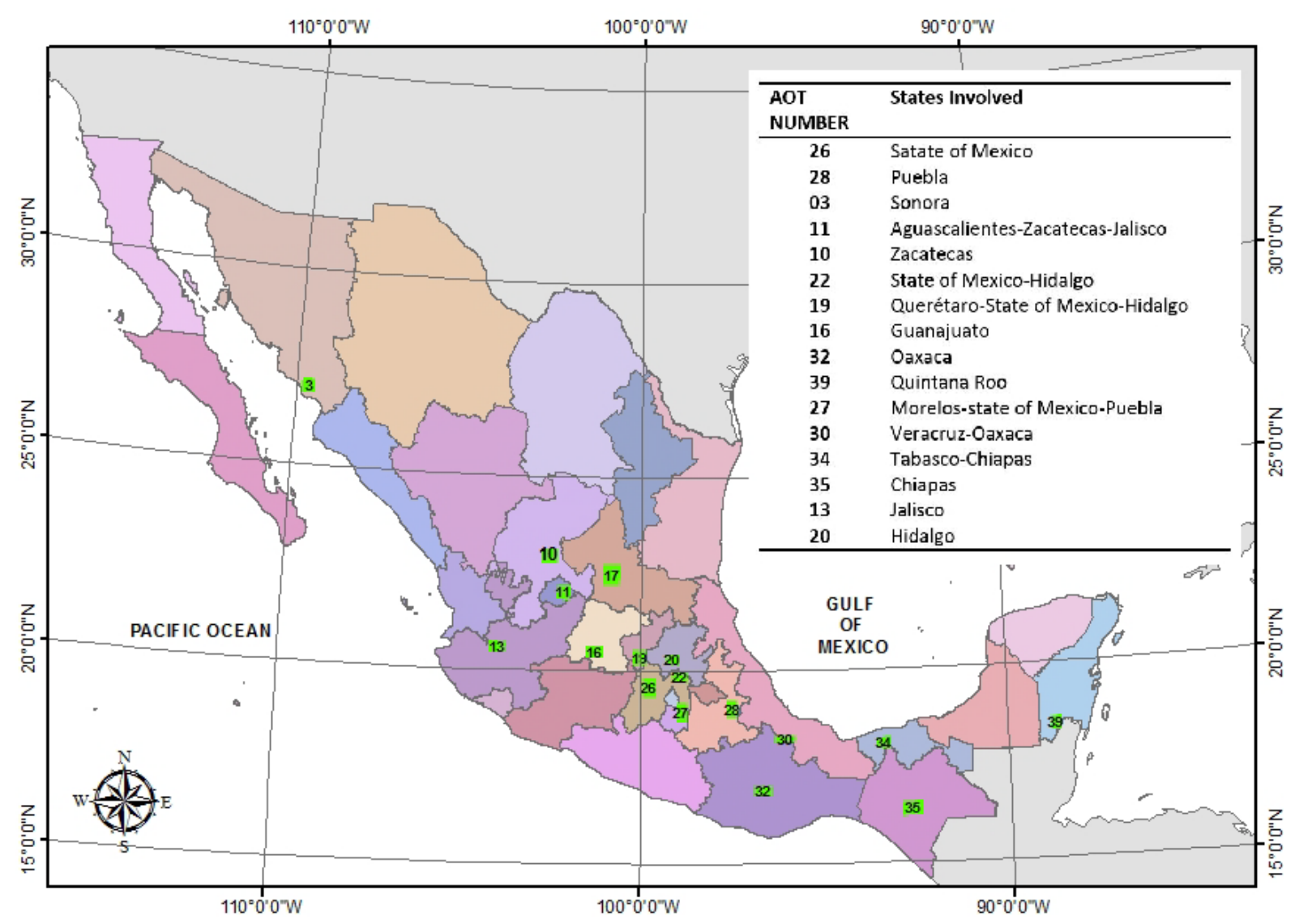

Figure 1. Agrotech Observatories (AOTs) in the Mexican republic, monitoring during 2011.

Table 1. Characteristics of AOT's in the Mexican republic.

\begin{tabular}{ccc}
\hline AOT number & Area (hectare) & States involved \\
\hline 26 & 200,000 & State of Mexico \\
28 & 150,000 & Puebla \\
03 & 160,000 & Sonora \\
11 & 160,000 & Aguascalientes-Zacatecas-Jalisco \\
10 & 200,000 & Zacatecas \\
22 & 120,000 & State of Mexico-Hidalgo \\
19 & 160,000 & Queretaro-State of Mexico-Hidalgo \\
16 & 150,000 & Guanajuato \\
32 & 150,000 & Oaxaca \\
39 & 120,000 & Quintana-Roo \\
27 & 150,000 & Morelos-State of Mexico-Puebla \\
30 & 120,000 & Veracruz-Oaxaca \\
34 & 120,000 & Tabasco-Chiapas \\
35 & 240,000 & Chiapas \\
13 & 150,000 & Jalisco \\
20 & 120,000 & Hidalgo \\
Total: & $2,470,000$ & 14 \\
\hline
\end{tabular}




\subsection{Satellite Images Used}

To determine the land use/cover in all AOTs, we used 31 panchromatic scenes and 31 multispectral scenes of SPOT-5, with 1A correction level, which were obtained from the receiving station SPOT-Mexico, supported by the Ministry of Agriculture. The spatial resolution of the panchromatic and multispectral images was 2.5 and 10 $\mathrm{m}$ respectively. A process of geometric correction and ortho-rectification was applied to the satellite imagery [11], using the Universal Transverse Mercator projection UTM, and WGS84 datum. To illustrate the procedure, we will refer it to the AOT 20 Hidalgo, where six SPOT 5 images (three panchromatic and three multispectral) were used.

\subsection{Agricultural Borderline}

By visual image analysis and photointerpretation, the agricultural borderline was established; the approach consisted of involving the use of patterns, texture, size, color and topological features among objects. A mosaic of images was generated to facilitate management and interpretation, thus obtaining a continuous area to define and identify the agricultural areas and perform the scanning process in an efficient manner. In this procedure, RGB band combinations were used to highlight the vegetation cover and attain greater accuracy in line drawing in digitization. For this case study, three SPOT-5 panchromatic and three multispectral images covering the "AOT 20 Hidalgo" were used (Table 2).

The level of detail of the information layer of the agricultural borderline plays an important role in the estimation of the agricultural surfaces and for the determination of land use; this layer supports an initial estimation of the extent of agricultural cover and provides a framework for sampling and for the generation of work units to be used in the classification and information extraction processes. Using the ArcGIS V-10.0 geographic information system (GIS) and a reference mesh, zooms were used on the RGB screen compounds at a 1:10,000 scale to preserve homogeneity in digitization (Figure 2).

\subsection{Segmentation}

The segments are geographical objects over which on-the-field sampling for collecting information about land use/cover is applied. These segments are delineated to fall within the limits of the agricultural borderline. To generate sampling segments within each AOTs, the [12] procedure is used. The spatial distribution of the segments in the AOTs was random utilizing a SIG. Coverage of the total AOT area with the segments is equal to or greater than 3 percent of the total agricultural area of the AOT. Figure 3 shows the distribution of the sampled segments, which was the basis of the geographical location of segments for gathering on the field information. As an example, for the case of "AOT 20 Hidalgo" the segmentation criteria were as follows:

- Segmentation percentage: 3 .

- Segment Size: 49 hectares.

- Segment width: 700.

- Distance (threshold): 0.4 .

- Number of replicas: 2.

- Number of segments: 55.

Table 2. Multispectral and panchromatic scenes used in “AOT 20 Hidalgo" in 2011.

\begin{tabular}{ccc}
\hline Sensor & K/J & Making scene \\
\hline Spot 5 panchromatic & $588-309$ & $16 / 11 / 2011$ \\
Spot 5 panchromatic & $588-310$ & $23 / 10 / 2011$ \\
Spot 5 panchromatic & $589-310$ & $04 / 11 / 2011$ \\
Spot 5 multispectral & $588-309$ & $16 / 11 / 2011$ \\
Spot 5 multispectral & $588-310$ & $23 / 10 / 2011$ \\
Spot 5 multispectral & $589-310$ & $04 / 11 / 2011$ \\
\hline
\end{tabular}




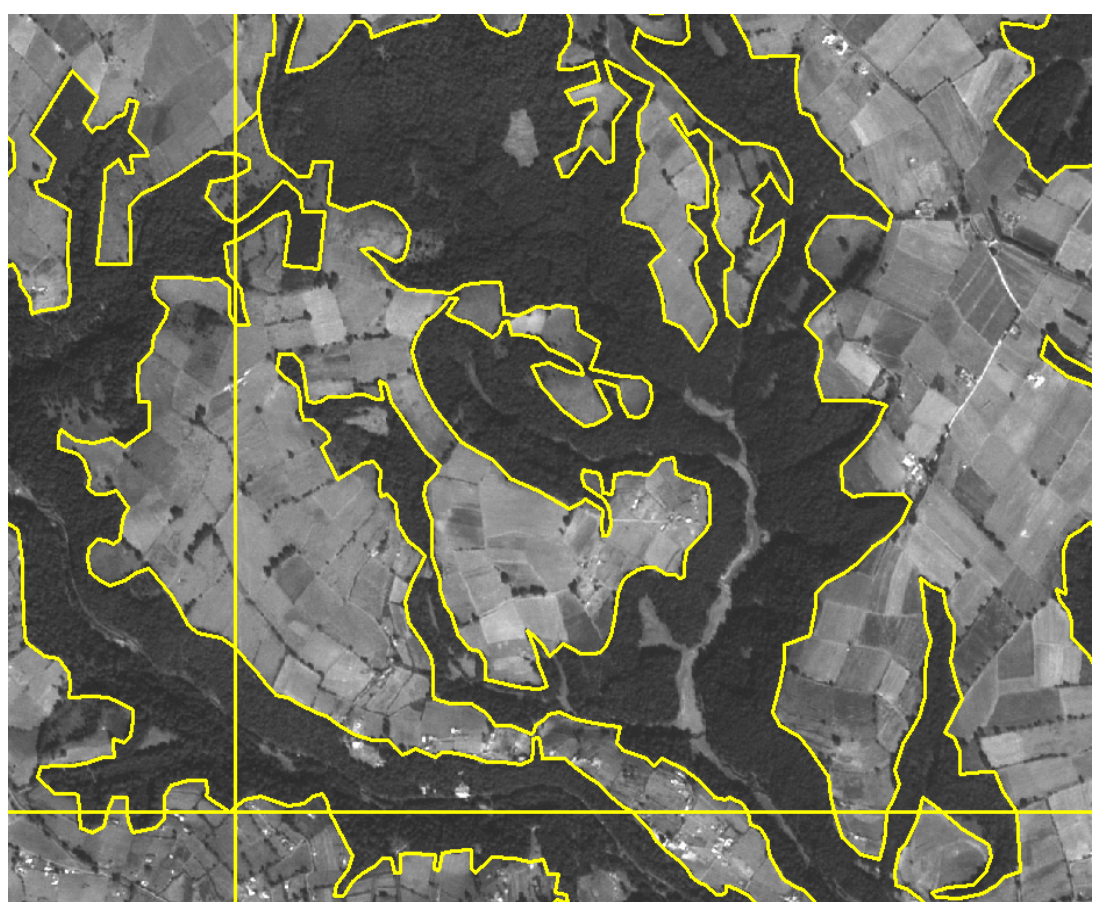

Figure 2. Details of digitization from a screen zoom.

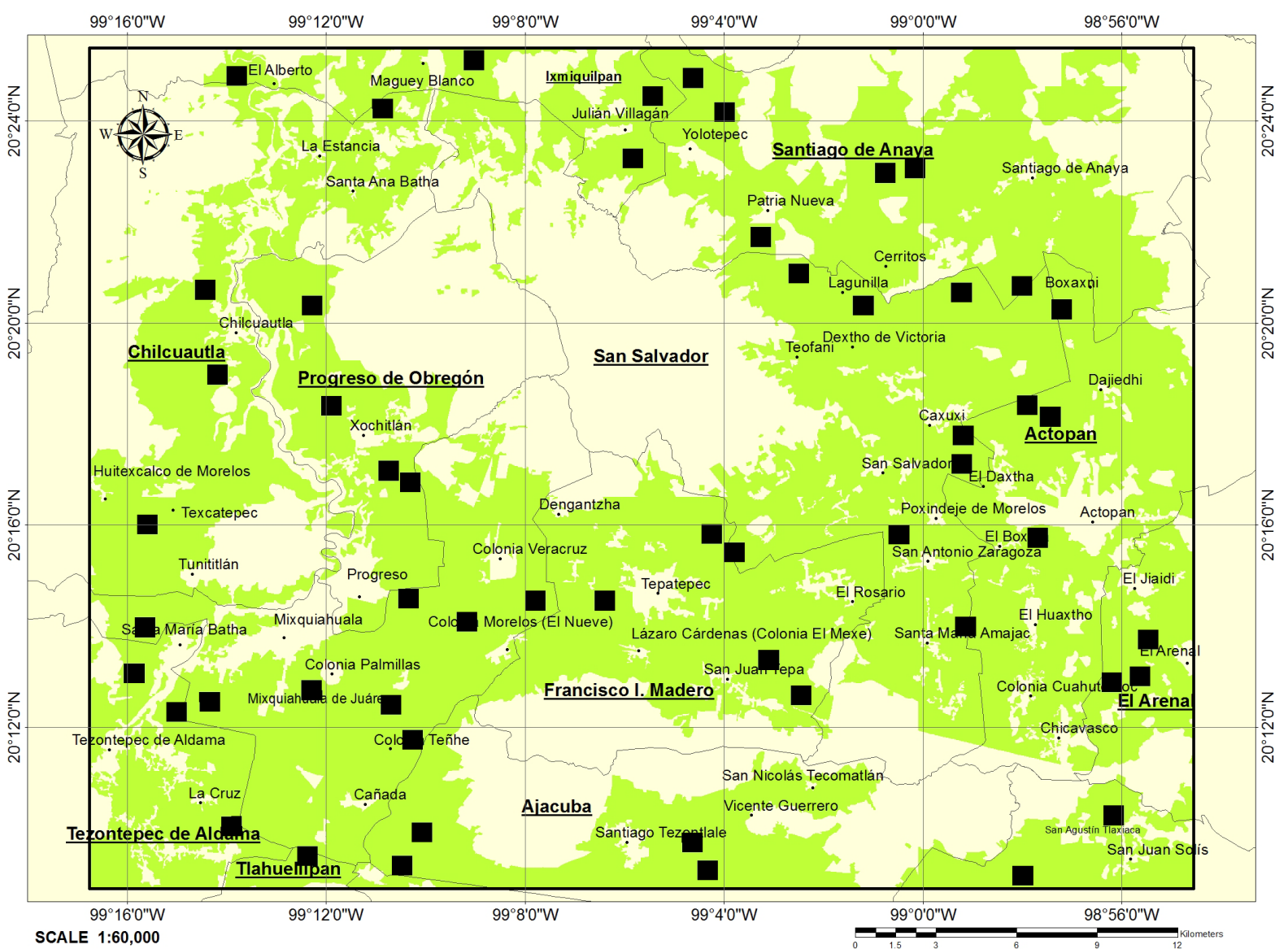

Figure 3. Distribution of sampled segments in the “AOT 20 Hidalgo”. 
Previous to fieldwork the parcels within each segment were digitized over ortho-rectified panchromatic images to obtain the parcel distribution, which was used in a training field context (Figure 4).

\subsection{Fieldwork}

In studies of land use/cover, fieldwork is very important to generate training points with GPS equipment and to assess the quality of the results. The fieldwork consisted of identify the different land use/cover within the segments. The composite RGBs for each segment were used to locate training sites; for this, the coordinates of the center points of each segment were captured with map-mobile computers and satellite navigators to locate the plots on the ground.

\subsection{Actual and Potential Crop Yields and Productivity}

The information captured on the field consisted of establishing the type and condition of the crop, its genotype and soil moisture regime, and of sampling actual yields to determine the productivity of different agricultural land covers. Furthermore, to know the surfaces and the potential crop yields, a yield forecasting technique based on an existing methodology was used [13].

Each work crew had a digital camera to get pictures of the sampled points. In Figure 5, some land use/cover sampled segments within the "AOT 20 Hidalgo" are shown as an example.

\subsection{Spectral Classes and Classification}

A buffer for all segments is generated so that the spectral signature of a given crop is more accurate. Within the

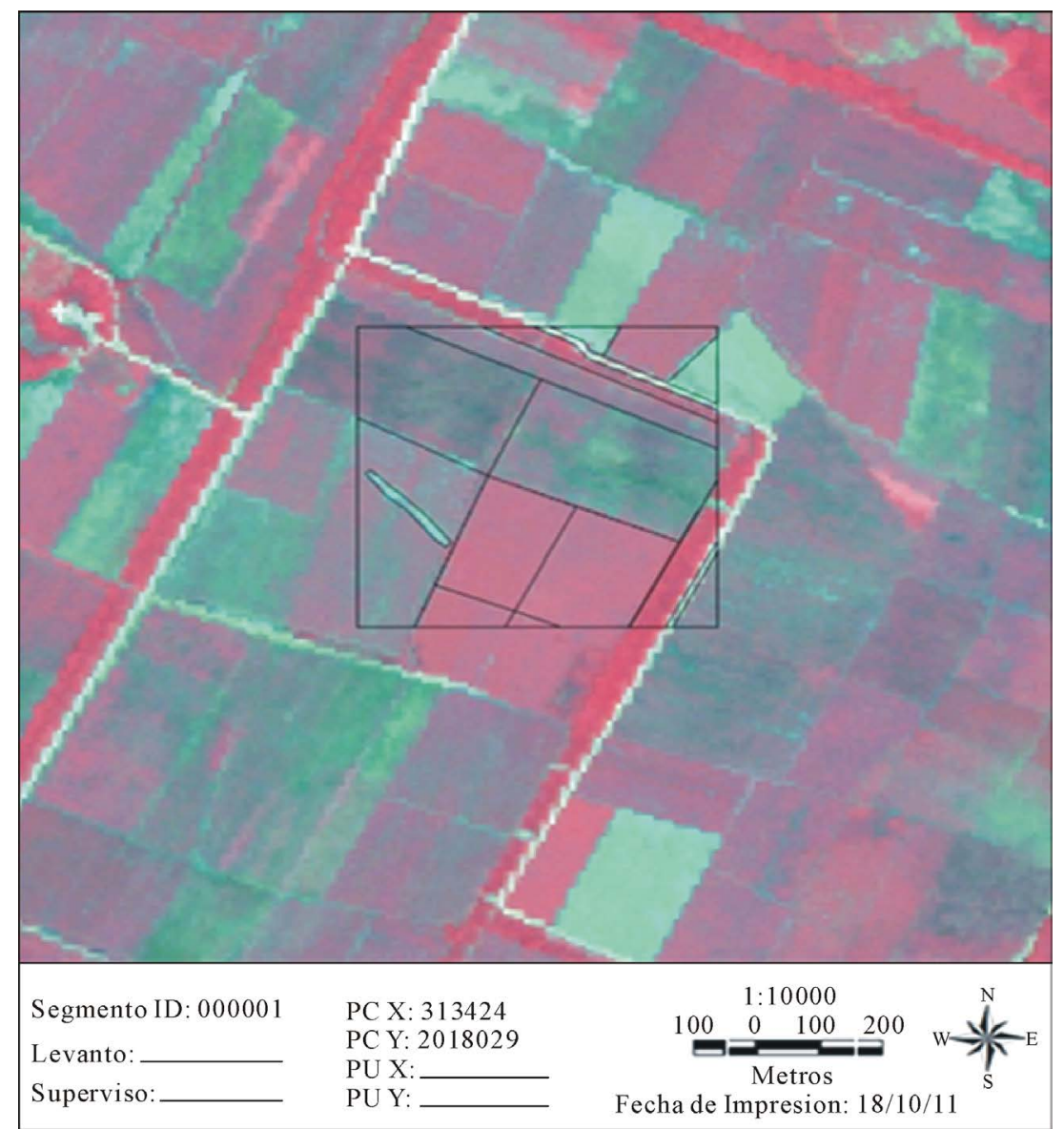

Figure 4. Crop land distribution in a segment, digitization of RGB composite from SPOT-5. 

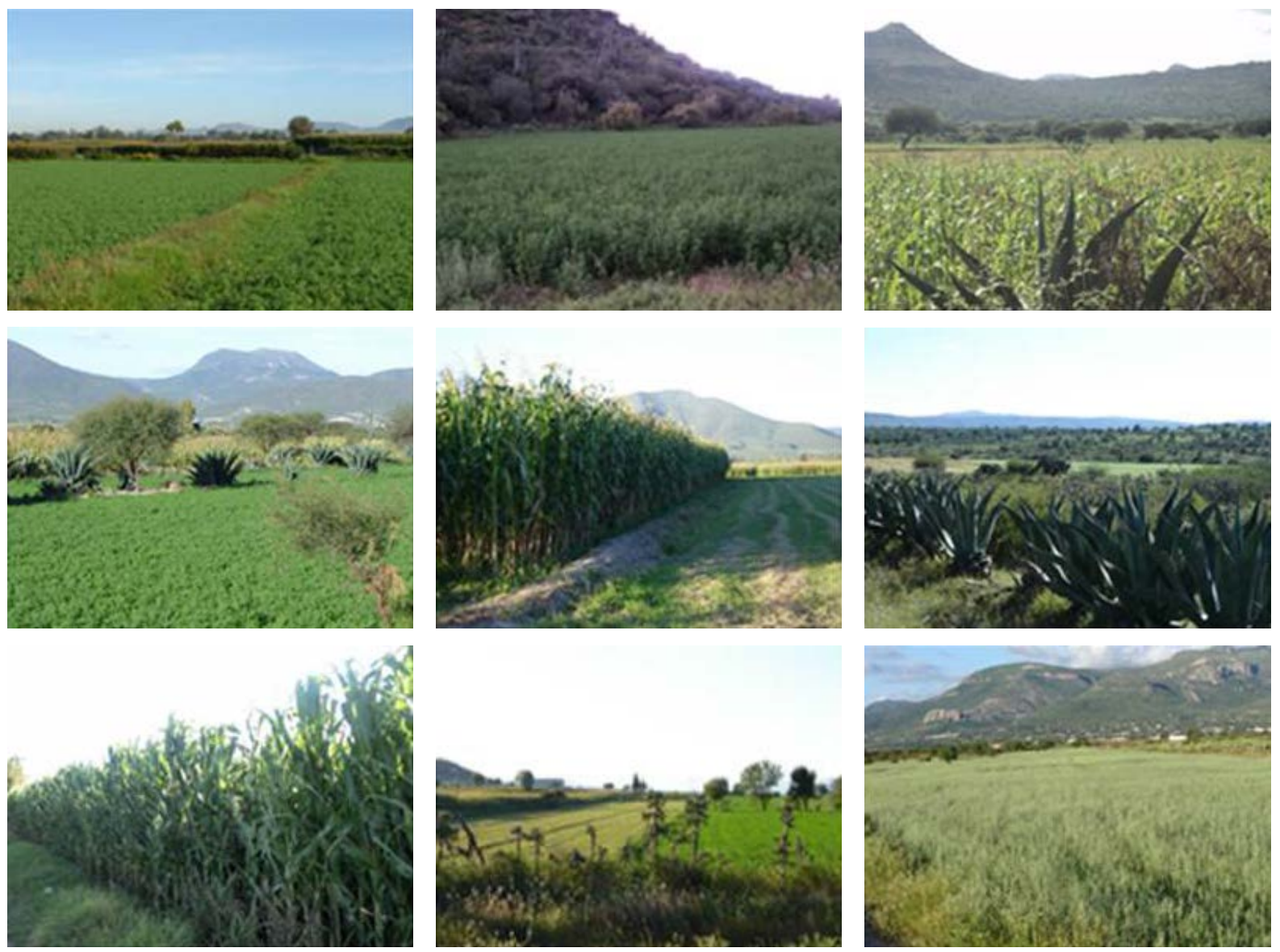

Figure 5. Crops and other land covers identified during fieldwork in the “AOT 20 Hidalgo”.

segments, the different land uses are defined and the data are transformed to a raster format in order to associate it with the image to be classified. Training fields for each spectral class are generated, and a digital classification is performed for discrimination of crops in the work units of the AOTs.

The classification of images is one of the most important parts of digital image analysis. Supervised classification algorithm with maximum likelihood classification was used in this study [11]. This method considers the weighting of the distances between the means of the digital levels of classes, using statistical parameters. The digital levels of each class conform to a normal distribution. This allows the description of a category by a probability function, from its mean vector and variance-covariance matrix. The calculation is performed for all categories involved in the classification, assigning the pixel to that category that maximizes the probability function.

For the digital classification the Erdas Imagine ${ }^{\circledR}$ processor was used. In the analysis of training fields only segments of replica \# 1 corresponding to $50 \%$ of the total segments visited were considered. The other $50 \%$ corresponding to replica \#2 were used for validation of the digital classification [12]. Once the spectral signatures generated (based on green, red and near infrared) a supervised classification for each unit of work on satellite imaging was realized, obtaining a thematic layer in raster format (*.img), with data about the value and name of the class, color table, statistics and histograms.

\subsection{Cartographic and Statistical Products}

The classification results were collected in a new data-image, similar to the originals with respect to structure and size, but where the digital number (DN) of each pixel does not correspond to a reflectance value but to an assigned category. This new image is the final result of the work, with two types of products: cartographic and statistical. 


\section{Results and Discussion}

\subsection{Agricultural Areas}

In all compact agricultural areas, the agricultural borderline cartography was updated by digitizing SPOT-5 Panchromatic images [14]. In order to obtain the thematic cartography within the agricultural borderline and the land use/cover cartographic formats with the following information were used: geographic coordinates, map title, map characteristics such as geodetic data and scale, etc., as well as the map legend, which contains the land use classes and land cover by crop. The cartographic edition process was realized with the (Arc/Gis v10.0) software.

Continuing with the example of "AOT 20 Hidalgo", the agricultural area is shown in Figure 6. The agricultural area occupied by "AOT 20 Hidalgo" is 67356.6 hectares, 56.1 percent compared to the total area of the AOT.

\subsection{Land Use/Cover Map}

Continuing with the example of the AOT 20 Hidalgo, the actual land use/cover was as follows: corn grain $22.4 \%$, alfalfa $21.9 \%$, oats $2.9 \%$, corn forage $2.8 \%$, beans $1.3 \%$, Opuntia $0.4 \%$ among others covers (Figure 7 ).

Table 3 shows that the largest area is occupied by the corn-grain crop; this is in accord with its economic and social relevance in the daily alimentary diet of the Mexican population, especially in the form of tortillas. The second largest area is occupied by alfalfa stands, an important forage crop whether as fresh-cut or dried, with a high demand in the central part of the country used as livestock feed. Oats and corn-forage crops are also used for this purpose but are grown to a lesser extent.

Other crops of economic and social importance are beans and maguey (Agave americana). The first crop is also a common staple of the daily diet in Mexico. Maguey, of which only 312.8 ha are reported, is used for the extraction of natural syrup, an input to the production of an indigenous fermented drink called pulque.

\subsection{Crops Yield, Actual and Potential Productivity}

Table 4 shows the actual and potential productivity of major crops identified in the "AOT 20 Hidalgo" with cultivated surfaces, as well as actual and potential yields. The volume of the production (ton) is the product of the cultivated surface (ha) and yield (ton $\mathrm{ha}^{-1}$ ).

Concerning the AOT 20 Hidalgo exemplified here, for all the crops that were analyzed the potential productivity is surpassed by the actual one. In the case of the corn-grain crop, the current yield of 7.6 ton $\cdot \mathrm{ha}^{-1}$ can potentially reach 12.0 ton ha $^{-1}$, with production volumes of 114972.8 ton to 232081.2 ton respectively.

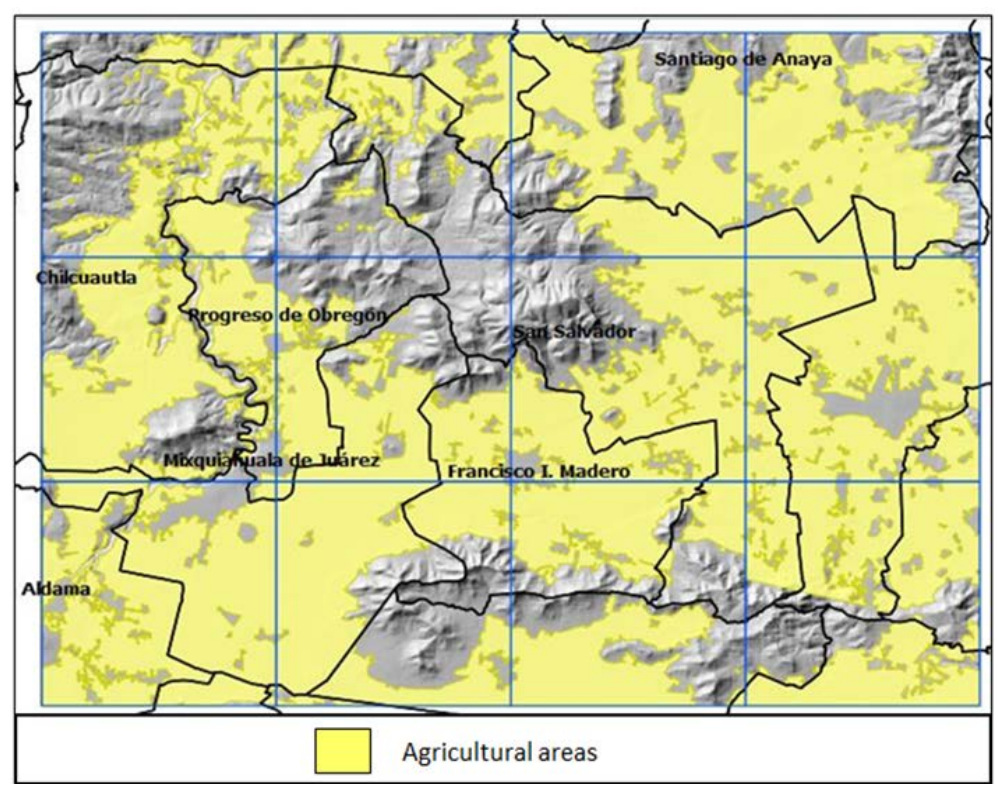

Figure 6. Map of agricultural areas in “AOT 20 Hidalgo”. 


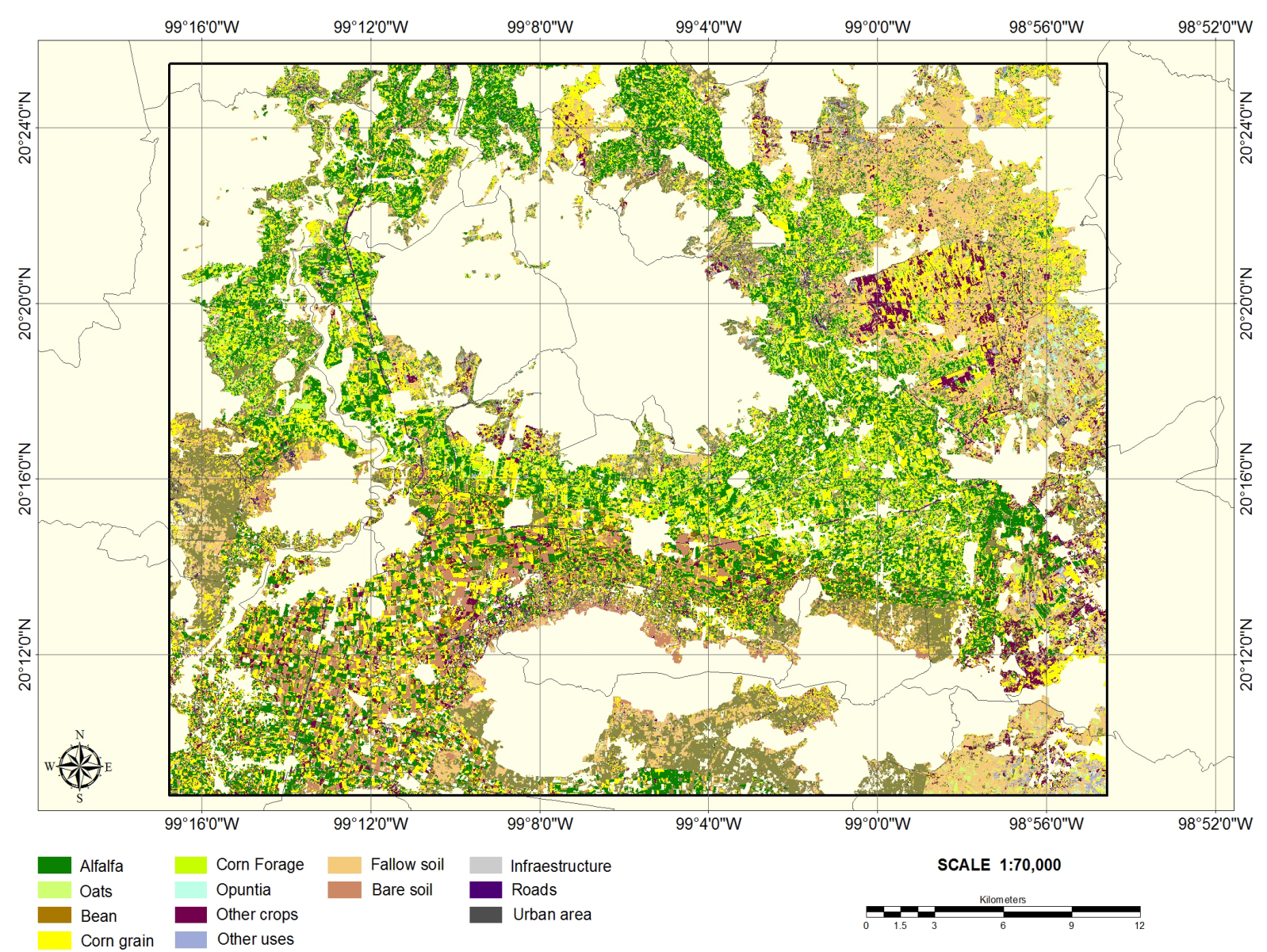

Figure 7. Land use/cover map of "AOT 20 Hidalgo".

Table 3. Surfaces of Land use/cover in "AOT 20 Hidalgo".

\begin{tabular}{cccc}
\hline Land use & Land cover & Surface (ha) & (\%) \\
\hline Agricultural & Corn-grain & 15128.0 & 22.4 \\
Agricultural & Alfalfa & 14750.8 & 21.9 \\
Agricultural & Oats & 1974.1 & 2.9 \\
Agricultural & Corn-forage & 1910.9 & 2.8 \\
Agricultural & Bean & 901.2 & 1.3 \\
Agricultural & Opuntia & 312.8 & 0.4 \\
Agricultural & Bare soil & 2707.1 & 4.0 \\
Agricultural & fallow soil & 13106.2 & 19.4 \\
Urban & Urban area & 1228.7 & 1.8 \\
Infrastructure & Roads & 755.1 & 1.1 \\
Other uses & Other uses & 14581.2 & 21.6 \\
Total area & & 67356.6 & 100.0 \\
\hline
\end{tabular}


Table 4. Agricultural land cover, actual and potential productivity of “AOT 20 Hidalgo”.

\begin{tabular}{ccccccc}
\hline \multirow{2}{*}{ Land cover } & \multicolumn{3}{c}{ Actual productivity } & \multicolumn{3}{c}{ Potential productivity } \\
\cline { 2 - 6 } & Surface (ha) & Yield (ton'ha ${ }^{-1}$ ) & $\begin{array}{c}\text { Production } \\
\text { volume (ton) }\end{array}$ & Surface (ha) & Yield (ton·ha ${ }^{-1}$ ) & $\begin{array}{c}\text { Production } \\
\text { volume (ton) }\end{array}$ \\
\hline Corn-grain & 15128.0 & 7.6 & 114972.8 & 19340.1 & 12.0 & 232081.2 \\
Alfalfa & 14750.8 & 12.0 & 177009.6 & 18439.2 & 17.0 & 313466.4 \\
Oats & 1974.1 & 10.6 & 20925.5 & 4435.5 & 15.0 & 66532.5 \\
Corn-forage & 1910.9 & 17.8 & 34014.0 & 8267.3 & 25.0 & 206682.5 \\
Bean & 901.2 & 2.3 & 2072.8 & 3241.7 & 3.8 & 12318.5 \\
\hline
\end{tabular}

The potential productivity can be achieved by taking into account: 1) the climatic and soil requirements of each crop to increase acreage, in particular for corn as illustrated; 2) the application of technological packages recommended by agricultural research institutions.

This requires a comprehensive and detailed knowledge of the climatic and edaphic resources and of the land use patterns within the compact agricultural areas as defined for the country. Therefore, it is very important to accurately know the land use/cover and geo-spatial distribution of crops, particularly in areas with a high productivity potential. Thus, land cover is defined as the observed (bio)-physical cover on the specific area surface. It includes vegetation and man-made features as well as corn crop, alfalfa, etc. On a fundamental level, land cover is the most important element for description and study of the environment [9], particularly the agricultural activity.

\section{Conclusion}

It is important to have current and accurate information to support federal government programs aimed at the rural sector in Mexico, particularly in areas of high productivity potential. Information of land use/cover is very important for the proposed productive restructuring actions of the Mexican agriculture. It is possible to improve production and productivity of the countryside, with studies of potential soil use. What is also needed is a more efficient national policy which incorporates technological recommendations generated by research institutions and supports decision makers within the Ministry of Agriculture as well as the country's farmers.

\section{References}

[1] Steffen, W., Crutzen, P.J. and McNeill, J.R. (2007) The Anthropocene: Are Humans Now Overwhelming the Great Forces of Nature. AMBIO-A Journal of the Human Environment, 36, 614-621. http://dx.doi.org/10.1579/0044-7447(2007)36[614:TAAHNO]2.0.CO;2

[2] Verburg, P.H., Erb, K.-H., Mertz, O. and Espindola, G. (2013) Land System Science: Between Global Challenges and Local Realities. Current Opinion in Environmental Sustainability, 5, 433-437. http://dx.doi.org/10.1016/j.cosust.2013.08.001

[3] Gutman, G., Janetos, A.C., Justice, C.O., Moran, E.F., Mustard, J.F., Rindfuss, R.R. and Cochrane, M.A. (2005) Land Change Science: Observing, Monitoring and Understanding Trajectories of Change on the Earth’s Surface. Springer, Berlin.

[4] Turner, B.L., Lambin, E.F. and Reenberg, A. (2007) The Emergence of Land Change Science for Global Environmental Change and Sustainability. Proceedings of the National Academy of Sciences, 104, 20666-20671. http://dx.doi.org/10.1073/pnas.0704119104

[5] Reenberg, A. (2009) Land System Science: Handling Complex Series of Natural and Socio-Economic Processes. Journal of Land Use Science, 4, 1-4. http://dx.doi.org/10.1080/17474230802645618

[6] Verburg, P.H., Erb, K.-H., Mertz, O. and Espindola, G. (2013) Land System Science: Between Global Challenges and Local Realities. Current Opinion in Environmental Sustainability, 5, 433-437. http://dx.doi.org/10.1016/j.cosust.2013.08.001

[7] Müller, D. and Munroe, D.K. (2014) Current and Future Challenges in Land Use Science. Journal of Land Use Science, 9, 133-142. http://dx.doi.org/10.1080/1747423X.2014.883731 
[8] Homer, C. and Barnes, C. (2009) Land Cover Institute, Mission. Center of Earth Resources Observation and Science (EROS) USGS-LCI. Sioux Falls, SD. Diptic.

[9] Herold, M., Latham, J.S., Di Gregorio, A. and Schmullius, C.C. (2006) Evolving Standards in Land Cover Characterization. Journal of Land Use Science, 1, 157-168. http://dx.doi.org/10.1080/17474230601079316

[10] Comber, A.J., Wadsworth, R.A. and Fisher, P.F. (2008) Using Semantics to Clarify the Conceptual Confusion between Land Cover and Land Use: The Example of “Forest”. Journal of Land Use Science, 3, 185-198. http://dx.doi.org/10.1080/17474230802434187

[11] Ustin, S. (2004) Remote Sensing for Natural Resources Management and Environmental Monitoring. 3rd Edition, Vol. 4, John Wiley \& Sons, Inc., Hoboken.

[12] Taylor, J., Sannier, C., Delince, J. and Gallego, J. (1997) Regional Crops Inventories in Europe Assisted by Remote Sensing: 1988-1993. Synthesis Report of the MARS Project-Action 1.

[13] Soria-Ruiz, J., Fernández-Ordoñez, Y.M. and Granados-Ramírez, R. (2004) Methodology for Prediction of Corn Yield Using Remote Sensing Satellite Data in Central Mexico. Investigaciones geográficas, 55, 61-78.

[14] ESRI (2011) ArcGis 10. Understanding Our World. Redlands. 
Scientific Research Publishing (SCIRP) is one of the largest Open Access journal publishers. It is currently publishing more than 200 open access, online, peer-reviewed journals covering a wide range of academic disciplines. SCIRP serves the worldwide academic communities and contributes to the progress and application of science with its publication.

Other selected journals from SCIRP are listed as below. Submit your manuscript to us via either submit@scirp.org or Online Submission Portal.
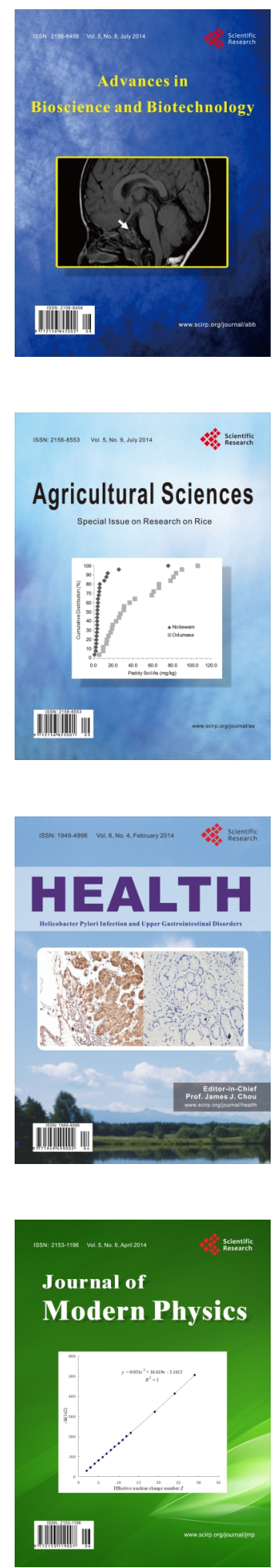
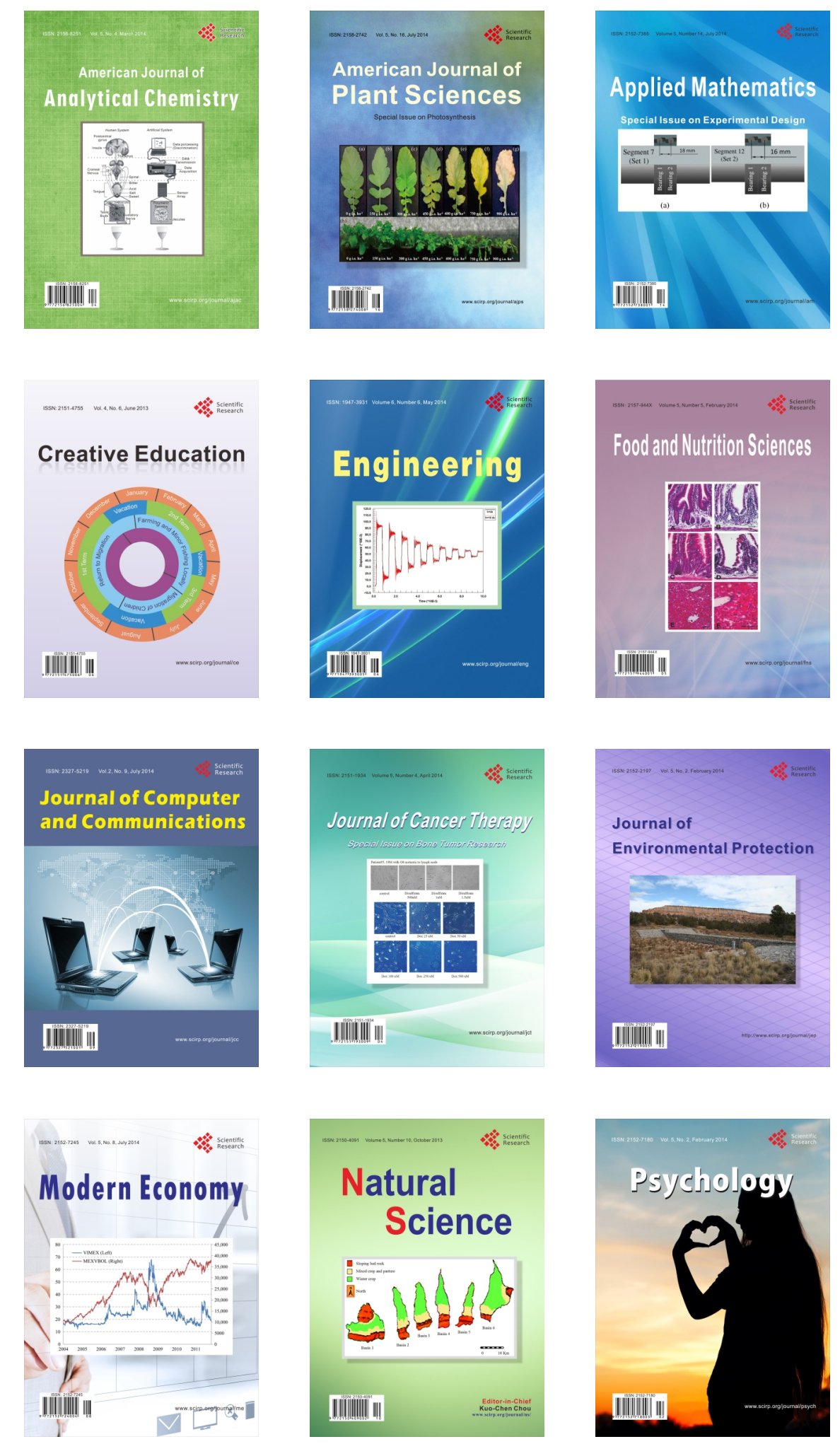